\title{
Comorbidity and survival of Danish breast cancer patients from 2000-20I I: a population-based cohort study
}

This article was published in the following Dove Press journal:

Clinical Epidemiology

I November 2013

Number of times this article has been viewed

\author{
Anne Gulbech Ording' \\ Deirdre P Cronin-Fenton' \\ Jacob Bonde Jacobsen' \\ Mette Nørgaard' \\ Reimar Wernich Thomsen' \\ Peer Christiansen ${ }^{2}$ \\ Mette Søgaard' \\ 'Department of Clinical \\ Epidemiology, ${ }^{2}$ Breast and Endocrine \\ Section, Department of Surgery P, \\ Aarhus University Hospital, Aarhus, \\ Denmark
}

Objective: Previous studies have suggested that breast cancer survival in Denmark has improved, primarily in cancer patients without comorbidity. We therefore conducted a population-based cohort study to examine recent temporal changes in survival and mortality among breast cancer patients with different extents of comorbidity.

Methods: We used population-based medical and administrative registries to identify breast cancer patients diagnosed between 2000 and 2011 in the Central Denmark Region. We defined comorbid diseases according to the Charlson Comorbidity Index (CCI), including a history of hospitalization for comorbid disease up to 10 years before breast cancer diagnosis. We studied the impact of comorbidities on overall 1- and 5-year survival in different calendar time periods, using a hybrid analysis for survival prediction in the most recent calendar periods.

Results: We included 9,329 breast cancer patients. The proportion of patients within different comorbidity categories remained stable from 2000 to 2011 . One-year survival improved from $91 \%$ in 2000-2002 to $95 \%$ in 2009-2011, while 5-year survival improved from $72 \%$ to a predicted $78 \%$. During the entire study period, comorbidity was a strong predictor of the survival of breast cancer patients. However, we observed improvements over time in 1- and 5 -year survival for all comorbidity groups. During the 12-year study period, the estimated 5-year survival for patients with a high comorbidity disease burden (CCI score $\geq 3$ ) increased from $25 \%$ to a predicted $50 \%$, and their 5-year age-adjusted mortality hazard ratio (HR) fell from 4.0 (95\% confidence interval [CI]: 3.0, 5.4) to 2.7 (95\% CI: $2.0,3.6)$, respectively, compared with patients with no comorbid disease.

Conclusion: Survival of breast cancer patients diagnosed in the Central Denmark Region improved from 2000 to 2011, regardless of the extent of comorbid disease.

Keywords: breast neoplasm, survival, mortality, comorbidity, prognosis

\section{Introduction}

Denmark currently has the second-highest breast cancer incidence and the highest mortality from breast cancer in Europe. ${ }^{1}$ Breast cancer risk increases with age, so breast cancer patients often have comorbid disease at the time of their breast cancer diagnosis. $^{2-4}$ In Denmark, this amounts to about $20 \%$ of all breast cancer patients. ${ }^{5}$ Several studies have documented that comorbid diseases negatively affect survival after breast cancer. ${ }^{6,7}$ Mortality in these patients may often be related to the comorbidities rather than to the breast cancer, ${ }^{8,9}$ in particular among patients with extensive comorbidity. ${ }^{10-12}$

Survival after breast cancer has improved in Denmark ${ }^{13}$ but, according to a recent Danish population-based study, the 5-year survival of breast cancer patients
Correspondence: Anne G Ording

Department of Clinical Epidemiology,

Aarhus University Hospital,

Olof Palmes Allé 43-45,

8200 Aarhus N, Denmark

Tel +4587168063

Fax $+4587 \quad 1672 \quad 15$

Email ao@dce.au.dk 
with a Charlson Comorbidity Index (CCI) score of $\geq 3$ has only increased from $42.0 \%$ in $1990-1994$ to $43.5 \%$ in 2000-2004. ${ }^{14}$ Another previous Danish population-based study reported slightly poorer survival over time among breast cancer patients with severe comorbidity between 1995 and $2005 .{ }^{5}$ The aim of this paper was to study temporal changes in mortality in a cohort of breast cancer patients diagnosed between 2000 and 2011 by extent of comorbid diseases, as defined by the CCI. ${ }^{15}$

\section{Materials and methods Study population}

This population-based cohort study was based in the Central Denmark Region, which has approximately 1.2 million inhabitants. The Danish National Health service provides universal, tax-supported health care, guaranteeing unfettered access to all general practitioners and hospitals. Accurate and unambiguous linkage of all registries at the individual level is possible in Denmark by means of the unique civil personal registration (CPR) number assigned to each Danish inhabitant at birth or immigration. ${ }^{16}$

\section{Identification of patients with breast cancer}

The Danish National Registry of Patients (NRP) contains information on all discharges from nonpsychiatric hospitals in Denmark since 1977 and from emergency room and outpatient visits at hospitals since $1995 .{ }^{17}$ Each hospital discharge or outpatient visit is recorded in the registry with one primary diagnosis and one or more secondary diagnoses classified according to the International Classification of Diseases, 8th edition (ICD-8) until the end of 1993, and ICD-10 thereafter. Using the NRP, we identified all female patients with an invasive breast cancer diagnosis (ICD-10 code C50) from January 1, 2000 to December 31, 2011. Patients with breast cancer diagnosed between 1977 and 1999 were excluded.

\section{Comorbid diseases at breast cancer diagnosis}

To assess patient comorbidity, the CCI score was computed at date of breast cancer diagnosis for each patient based on NRP records up to 10 years preceding the date of the breast cancer diagnosis (Table S1). ${ }^{15}$ The CCI has been adapted and validated for use with hospital discharge data for the prediction of short- and long-term mortality. ${ }^{15,18}$ The following disease categories are included: liver diseases; myocardial infarction; congestive heart failure; peripheral vascular disease; chronic pulmonary disease; cerebrovascular disease; hemiplegia; dementia; connective tissue disease; ulcer disease; diabetes; renal disease; cancer; and HIV/AIDS. Breast cancer diagnoses were excluded when we computed the CCI score. Furthermore, cancer diagnoses within 60 days before the breast cancer diagnosis were excluded from the calculations, in order to eliminate possible nonspecific cancer diagnoses related to the breast cancer diagnosis. We categorized comorbidities as none (CCI score $=0)$, medium (CCI score $=1-2$ ), or high (CCI score $\geq 3$ ).

\section{Vital status}

Members of the study cohort were linked via their CPR number to the Danish Civil Registration System to obtain information on vital status. ${ }^{16}$ This registry has recorded all changes in vital status and migration for the entire Danish population since 1968 , with daily electronic updates. The outcome was overall mortality defined as death from any cause. Follow-up was through patient date of death, emigration, or December 31, 2011, whichever occurred first.

\section{Statistical analysis}

The prevalence of comorbidity was computed in study patients during four 3-year calendar time periods (2000-2002, 2003-2005, 2006-2008, and 2009-2011). For each comorbidity category, we constructed Kaplan-Meier survival curves for the different calendar time periods. Next, we used Cox proportional hazards regression to compute 1- and 5-year crude and age-adjusted hazard ratios as a measure of relative overall mortality to assess the association of comorbidity with mortality using a CCI score $=0$ as the reference category in each calendar time period. In the latter periods, we predicted 1- and 5-year survival using a hybrid analysis in which survival was estimated using the survival experience of patients in the previous calendar time periods. ${ }^{19}$ Breast cancer stage and grade were considered to be causal intermediates in the association between comorbidity and mortality, thus not included in the analyses. The proportional hazards assumption was assessed graphically and found to be appropriate. All analyses were performed using SAS software (v 9.2; SAS Institute Inc, Cary, NC, USA). The Danish Data Protection Agency approved the study (record number 2009-41-3866).

\section{Results}

The study included 9,329 women diagnosed with breast cancer between 2000 and 2011. As shown in Tables 1 and $\mathrm{S} 2$, the proportion of patients across different CCI score categories and individual comorbid diseases was relatively 
Table I Distribution of breast cancer patients diagnosed between 2000 and $20 \mathrm{II}$ by $\mathrm{CCl}$ score in four calendar time periods

\begin{tabular}{|c|c|c|c|c|}
\hline & 2000-2002 & 2003-2005 & 2006-2008 & 2009-201I \\
\hline Patients, n (\%) & $1,980(21)$ & $\mathrm{I}, 994(2 \mathrm{I})$ & $2,410(26)$ & $2,945(32)$ \\
\hline $\begin{array}{l}\text { Median age } \\
\text { in years (IQR) }\end{array}$ & $62(53,74)$ & $61(52,72)$ & $63(54,7 \mathrm{I})$ & $63(54,70)$ \\
\hline \multicolumn{5}{|c|}{ Age group, $\mathrm{n}(\%)$} \\
\hline $15-49$ years & $380(19)$ & $416(21)$ & $395(16)$ & $459(16)$ \\
\hline 50-74 years & $\mathrm{I}, \mathrm{I} 34$ (57) & $\mathrm{I}, 156(58)$ & $1,569(65)$ & $1,996(68)$ \\
\hline$\geq 75$ years & $466(24)$ & $422(2 I)$ & $446(19)$ & $490(17)$ \\
\hline \multicolumn{5}{|c|}{$\mathrm{CCl}$ score, $\mathrm{n}(\%)$} \\
\hline 0 & I,567 (79) & $\mathrm{I}, 557(78)$ & $\mathrm{I}, 862(77)$ & $2,290(78)$ \\
\hline $1-2$ & $344(17)$ & $349(18)$ & $445(18)$ & $536(18)$ \\
\hline$\geq 3$ & $69(3)$ & $88(4)$ & $103(4)$ & $119(4)$ \\
\hline \multicolumn{5}{|c|}{ Median age in years (IQR) by $\mathrm{CCl}$ score } \\
\hline 0 & $60(5 I, 7 I)$ & $59(50,69)$ & $61(53,68)$ & $62(53,68)$ \\
\hline $1-2$ & $71(60,80)$ & $71(60,80)$ & $68(61,78)$ & $68(61,78)$ \\
\hline$\geq 3$ & $74(65,81)$ & $75(63,81)$ & $7 \mid(63,79)$ & $71(65,79)$ \\
\hline
\end{tabular}

Abbreviations: $\mathrm{CCl}$, Charlson Comorbity Index; IQR, interquartile range.

constant over the 4 calendar time periods. The number of breast cancer patient diagnoses increased markedly between 2000 and 2011, almost doubling for patients aged between 50 and 74 years. The proportion of patients aged 50 to 74 years increased markedly in each time period from $57 \%$ in 2000-2002 to 68\% in 2009-2011. In contrast, the proportion of patients aged $75+$ years fell from $24 \%$ to $17 \%$.

\section{Survival}

Table 2 presents survival and relative mortality across calendar periods and age groups. Overall, the 1-year survival improved between 2000-2002 and 2009-2011, from 91\% to $95 \%$, while 5 -year survival improved from $72 \%$ to $78 \%$. The 1- and 5-year survival remained rather constant over time among patients aged 15-49 years and for patients aged $\geq 75$ years, but increased from $93 \%$ to $97 \%$ and from $77 \%$ to $84 \%$, respectively, for patients aged between 50 and 74 (Table 2).

Figure 1 shows the Kaplan-Meier survival curves for breast cancer patients in the four calendar time periods stratified by CCI score. For patients with a CCI score of $\geq 3$, survival improved markedly after the period 2000-2002.

Table 3 shows that patients with high CCI scores had higher 1- and 5-year mortality compared with those with low CCI scores, regardless of calendar period. However, 1-year survival improved over time for all three CCI categories. Most of the 1-year survival improvement in all CCI categories seemed to happen early in the study period, ie, between 2000-2002 and 2003-2005, in particular for the CCI score $\geq 3$ patients. 5 -year survival also improved over time
Table 2 One- and 5-year survival and relative mortality stratified by four calendar time periods and age group of breast cancer diagnosis

\begin{tabular}{|c|c|c|c|c|}
\hline & \multicolumn{4}{|c|}{ Year of diagnosis } \\
\hline & 2000-2002 & 2003-2005 & 2006-2008 & 2009-20I I \\
\hline \multicolumn{5}{|l|}{ I year } \\
\hline Survival & $\begin{array}{l}91 \% \\
\text { (90\%-93\%) }\end{array}$ & $\begin{array}{l}94 \% \\
\text { (93\%-95\%) }\end{array}$ & $\begin{array}{l}94 \% \\
\text { (93\%-95\%) }\end{array}$ & $\begin{array}{l}95 \% \\
(94 \%-96 \%)\end{array}$ \\
\hline Adjusted & I & 0.66 & 0.73 & 0.59 \\
\hline $\mathrm{MRR}^{\mathrm{a}}$ & (reference) & $(0.52-0.83)$ & $(0.59-0.91)$ & $(0.47-0.74)$ \\
\hline \multicolumn{5}{|l|}{5 years } \\
\hline Survival & $\begin{array}{l}72 \% \\
(70 \%-74 \%)\end{array}$ & $\begin{array}{l}75 \% \\
(73 \%-77 \%)\end{array}$ & $\begin{array}{l}75 \% \\
(74 \%-77 \%)^{b}\end{array}$ & $\begin{array}{l}78 \% \\
(76 \%-80 \%)^{b}\end{array}$ \\
\hline Adjusted & I & 0.87 & 0.87 & 0.78 \\
\hline $\mathrm{MRR}^{\mathrm{a}}$ & (reference) & $(0.77-0.98)$ & $(0.77-0.98)^{\mathrm{b}}$ & $(0.69-0.87)^{\mathrm{b}}$ \\
\hline \multicolumn{5}{|l|}{ Age group } \\
\hline \multicolumn{5}{|l|}{ I5-49 years } \\
\hline $\begin{array}{l}\text { I-year } \\
\text { survival }\end{array}$ & $\begin{array}{l}97 \% \\
(95 \%-98 \%)\end{array}$ & $\begin{array}{l}99 \% \\
(97 \%-99 \%)\end{array}$ & $\begin{array}{l}99 \% \\
\text { (97\%-99\%) }\end{array}$ & $\begin{array}{l}97 \% \\
\text { (95\%-98\%) }\end{array}$ \\
\hline $\begin{array}{l}\text { 5-year } \\
\text { survival }\end{array}$ & $\begin{array}{l}85 \% \\
(81 \%-88 \%)\end{array}$ & $\begin{array}{l}86 \% \\
(82 \%-89 \%)\end{array}$ & $\begin{array}{l}89 \% \\
(86 \%-92 \%)^{b}\end{array}$ & $\begin{array}{l}87 \% \\
(84 \%-90 \%)^{b}\end{array}$ \\
\hline \multicolumn{5}{|l|}{ 50-74 years } \\
\hline $\begin{array}{l}\text { I-year } \\
\text { survival }\end{array}$ & $\begin{array}{l}93 \% \\
(92 \%-95 \%)\end{array}$ & $\begin{array}{l}96 \% \\
(94 \%-97 \%)\end{array}$ & $\begin{array}{l}95 \% \\
(94 \%-96 \%)\end{array}$ & $\begin{array}{l}97 \% \\
(96 \%-98 \%)\end{array}$ \\
\hline $\begin{array}{l}\text { 5-year } \\
\text { survival }\end{array}$ & $\begin{array}{l}77 \% \\
(74 \%-79 \%)\end{array}$ & $\begin{array}{l}80 \% \\
(78 \%-82 \%)\end{array}$ & $\begin{array}{l}80 \% \\
(78 \%-82 \%)^{b}\end{array}$ & $\begin{array}{l}84 \% \\
(82 \%-85 \%)^{b}\end{array}$ \\
\hline \multicolumn{5}{|l|}{$\geq 75$ years } \\
\hline $\begin{array}{l}\text { I-year } \\
\text { survival }\end{array}$ & $\begin{array}{l}82 \% \\
(78 \%-85 \%)\end{array}$ & $\begin{array}{l}85 \% \\
(82 \%-88 \%)\end{array}$ & $\begin{array}{l}83 \% \\
(79 \%-86 \%)\end{array}$ & $\begin{array}{l}84 \% \\
(80 \%-87 \%)\end{array}$ \\
\hline $\begin{array}{l}\text { 5-year } \\
\text { survival }\end{array}$ & $\begin{array}{l}50 \% \\
(45 \%-54 \%)\end{array}$ & $\begin{array}{l}50 \% \\
(45 \%-54 \%)\end{array}$ & $\begin{array}{l}48 \% \\
(43 \%-52 \%)^{b}\end{array}$ & $\begin{array}{l}48 \% \\
(43 \%-52 \%)^{b}\end{array}$ \\
\hline
\end{tabular}

Notes: $95 \%$ confidence intervals are presented in brackets. ${ }^{\text {aAdjusted for differences }}$ in age and comorbidity; bredicted values.

Abbreviation: MRR, mortality rate ratio.

in all CCI categories, with most pronounced improvements seen among CCI score $\geq 3$ patients - from $25 \%$ in 2000-2002 to a predicted 50\% in 2009-2011 (Table 3).

\section{Mortality}

The mortality across calendar periods was rather constant from 2003-2005 (Table 3). Compared with 1-year mortality in patients with no recorded comorbidity, the adjusted 1-year mortality hazard ratio (HR) for patients with a CCI score of 1-2 remained similar over time, ie, $\mathrm{HR}=1.8(95 \%$ confidence interval [CI]: 1.3, 2.6) in 2000-2002 and $\mathrm{HR}=1.9(95 \% \mathrm{CI}$ : $1.2,2.8)$ in 2009-2011. The corresponding 5-year mortality HRs were $1.4(95 \%$ CI: 1.1, 1.7) in 2000-2002 and $1.8(95 \%$ CI: $1.5,2.2)$ in 2009-2011. For patients with a CCI score of $\geq 3$, the adjusted 1-year mortality HRs compared with patients with no recorded comorbidity were $5.4(3.5,8.5)$ in 2000-2002 and $5.7(3.6,9.2)$ in 2009-2011. The 5-year mortality HRs were 4.0 (95\% CI: 3.0, 5.4) in 2000-2002 and 2.7 (95\% CI: 2.0, 3.6) in 2009-2011, compared with patients without comorbidity. 
Table 3 One- and 5-year survival and relative mortality for patients diagnosed with breast cancer in four calendar time periods stratified by Charlson Comorbidity Index score

\begin{tabular}{|c|c|c|c|}
\hline \multirow[t]{2}{*}{ Year of diagnosis } & \multicolumn{3}{|c|}{ Charlson comorbidity index score } \\
\hline & 0 & $\mathrm{I}-2$ & $\geq 3$ \\
\hline \multicolumn{4}{|l|}{ 2000-2002 } \\
\hline \multicolumn{4}{|l|}{ I year } \\
\hline Survival & $\begin{array}{l}94 \% \\
(93 \%-95 \%)\end{array}$ & $\begin{array}{l}86 \% \\
(82 \%-89 \%)\end{array}$ & $\begin{array}{l}62 \% \\
(50 \%-73 \%)\end{array}$ \\
\hline Adjusted $M_{R R}$ & I (reference) & $1.8(1.3-2.6)$ & $5.4(3.5-8.5)$ \\
\hline \multicolumn{4}{|l|}{5 years } \\
\hline Survival & $\begin{array}{l}76 \% \\
(74 \%-78 \%)\end{array}$ & $\begin{array}{l}63 \% \\
(57 \%-68 \%)\end{array}$ & $\begin{array}{l}25 \% \\
(15 \%-35 \%)\end{array}$ \\
\hline Adjusted $\mathrm{MRR}^{\mathrm{a}}$ & I (reference) & $1.4(1.1-1.7)$ & $\begin{array}{l}4.0 \\
(3.0-5.4)\end{array}$ \\
\hline \multicolumn{4}{|l|}{ 2003-2005 } \\
\hline \multicolumn{4}{|l|}{ I year } \\
\hline Survival & $\begin{array}{l}96 \% \\
(95 \%-97 \%)\end{array}$ & $\begin{array}{l}90 \% \\
(87 \%-93 \%)\end{array}$ & $\begin{array}{l}77 \% \\
(67 \%-85 \%)\end{array}$ \\
\hline Adjusted $M R^{a}$ & I (reference) & $1.6(1.1-2.5)$ & $3.49(2.1-5.9)$ \\
\hline \multicolumn{4}{|l|}{5 years } \\
\hline Survival & $\begin{array}{l}80 \% \\
(78 \%-82 \%)\end{array}$ & $\begin{array}{l}61 \% \\
(56 \%-66 \%)\end{array}$ & $\begin{array}{l}43 \% \\
(33 \%-53 \%)\end{array}$ \\
\hline Adjusted $\mathrm{MRR}^{\mathrm{a}}$ & (reference) & $1.7(1.3-2.0)$ & $2.5(1.9-3.4)$ \\
\hline \multicolumn{4}{|l|}{ 2006-2008 } \\
\hline \multicolumn{4}{|l|}{ I year } \\
\hline Survival & $\begin{array}{l}95 \% \\
\text { (94\%-96\%) }\end{array}$ & $\begin{array}{l}91 \% \\
(88 \%-93 \%)\end{array}$ & $\begin{array}{l}75 \% \\
(65 \%-82 \%)\end{array}$ \\
\hline Adjusted MRR ${ }^{a}$ & I (reference) & $1.4(0.9-2.0)$ & $3.8(2.4-6.0)$ \\
\hline \multicolumn{4}{|l|}{5 years } \\
\hline Survival & $\begin{array}{l}80 \% \\
(78 \%-82 \%)^{b}\end{array}$ & $\begin{array}{l}62 \% \\
(58 \%-67 \%)^{b}\end{array}$ & $\begin{array}{l}47 \% \\
(37 \%-56 \%)^{b}\end{array}$ \\
\hline Adjusted MRR & I (reference) & $1.6(1.3-1.9)^{b}$ & $2.4(1.8-3.3)^{\mathrm{b}}$ \\
\hline \multicolumn{4}{|l|}{ 2009-20I I } \\
\hline \multicolumn{4}{|l|}{ I year } \\
\hline Survival & $\begin{array}{l}97 \% \\
(96 \%-98 \%)\end{array}$ & $\begin{array}{l}92 \% \\
(89 \%-94 \%)\end{array}$ & $\begin{array}{l}74 \% \\
(64 \%-81 \%)\end{array}$ \\
\hline Adjusted MRR ${ }^{a}$ & I (reference) & $1.9(1.2-2.8)$ & $5.7(3.6-9.2)$ \\
\hline \multicolumn{4}{|l|}{5 years } \\
\hline Survival & $\begin{array}{l}83 \% \\
(81 \%-84 \%)^{b}\end{array}$ & $\begin{array}{l}64 \% \\
(59 \%-68 \%)^{b}\end{array}$ & $\begin{array}{l}50 \% \\
(40 \%-59 \%)^{b}\end{array}$ \\
\hline Adjusted MRR ${ }^{a}$ & I (reference) & $1.8(1.5-2.2)^{b}$ & $2.7(2.0-3.6)^{b}$ \\
\hline
\end{tabular}

Notes: $95 \%$ confidence intervals are presented in brackets. ${ }^{2}$ Adjusted for differences in age; bredicted values.

Abbreviation: MRR, mortality rate ratio.

\section{Discussion}

This large, population-based study showed improved 1- and 5-year survival of breast cancer patients diagnosed in the Central Denmark Region from 2000 through 2011. Comorbidity was a strong predictor of breast cancer survival. Nonetheless, we observed marked improvements in survival for all comorbidity groups. This survival improvement over time was even seen among patients with the highest comorbidity burden (CCI scores $\geq 3$ ), and corresponded to a decreased 5-year mortality HR compared with patients with no comorbid diseases (CCI score $=0)$.
Our study has both strengths and weaknesses. We used nationwide administrative and medical registries with prospectively collected data to identify breast cancer patients, comorbid diseases, and vital status, thereby avoiding selection bias and loss to follow-up. We obtained our information on breast cancer diagnoses from the NRP, which is regularly updated, allowing us to include the newest available data on breast cancer cases in Denmark. Moreover, the validity of breast cancer diagnoses recorded in the NRP is high. ${ }^{20}$

We used the CCI as a measure of the comorbidity burden. This index has been validated as a predictor of mortality in breast cancer patients and is often used in breast cancer research, allowing for comparison of our results with previous studies. The positive predictive values of diseases included in the CCI collected from the NRP have been shown to be high. ${ }^{21}$ However, as outpatient diagnoses were first added to the NRP in 1995, our study may be prone to nondifferential misclassification of the CCI score. Such misclassification would result if the inclusion of outpatient diagnoses increases the recorded comorbidity in the NRP and the measured comorbidity burden over time. Outpatient diagnoses are likely to be less severe than inpatient diagnoses, which may have contributed to the improvement in survival among patients with severe comorbidity. On the other hand, the effect of including outpatient diagnoses since 1995 should have resulted in a survival improvement before 2011, which was not the case. ${ }^{5,14}$ Furthermore, we lacked information on lifestyle-related risk factors (such as body mass index, smoking habits, and alcohol consumption), breast cancer stage, cancer treatment, and medication prescribed for the comorbid diseases, which could all affect the mortality rate.

We note relatively few patients with a CCI score $\geq 3$, and estimates were therefore imprecise. Nonetheless, our findings are consistent with previous studies, which have indicated higher mortality among breast cancer patients with comorbidity compared with those without comorbidity. ${ }^{5,14}$ There are several plausible explanations for this survival disparity. First, severe comorbidity could increase mortality independent of breast cancer, which in itself has a good prognosis. Second, women with extensive comorbid disease may have their cancer diagnosed at a later stage because comorbidity may mask any evidence of an underlying cancer. ${ }^{22}$ On the other hand, other studies have found a higher prevalence of comorbidity in earlier stages of breast cancer, probably because patients with comorbidity often require frequent medical care. ${ }^{23,24}$ Third, treatment options may be restricted in patients with severe comorbidity, who may not tolerate aggressive cancer treatment. ${ }^{25,26}$

Yet, in contrast to a recent Danish 5-year follow-up of breast cancer patients diagnosed from 1990 to 2004, which did 
A

Breast cancer

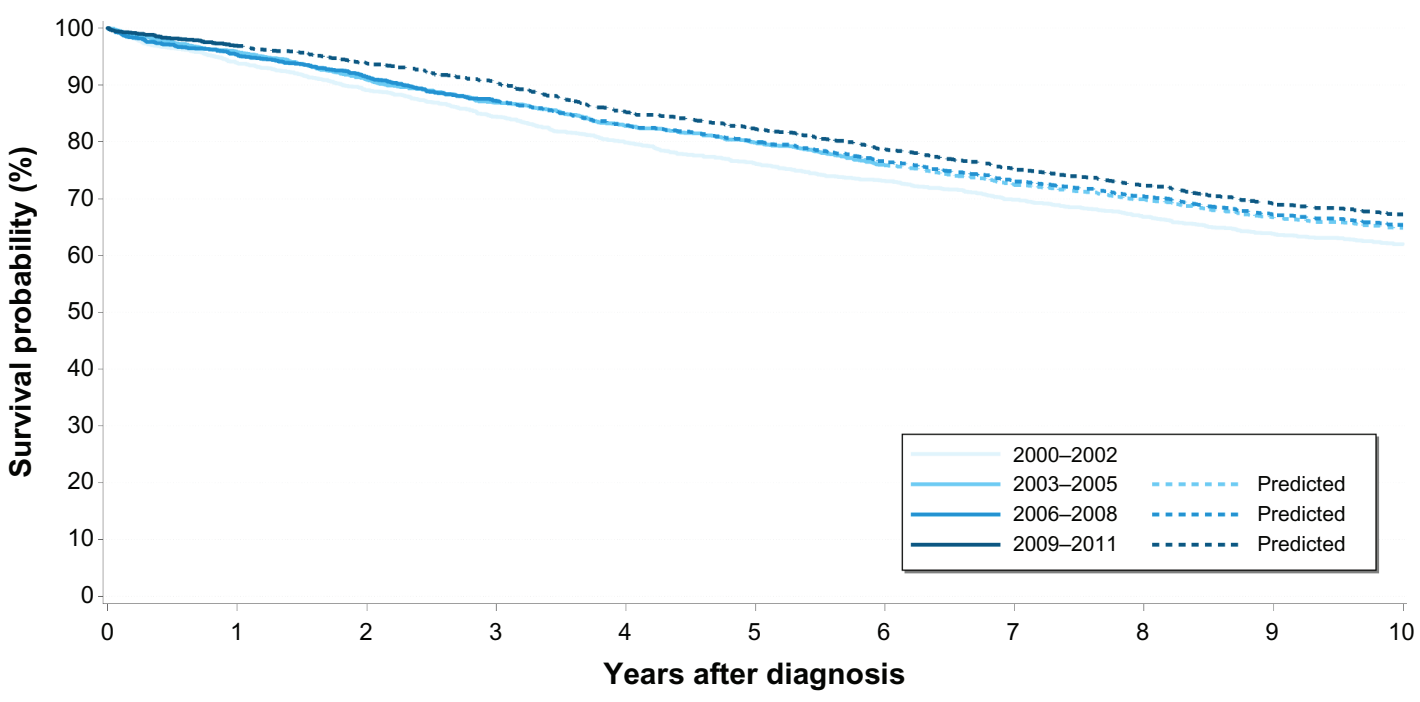

B

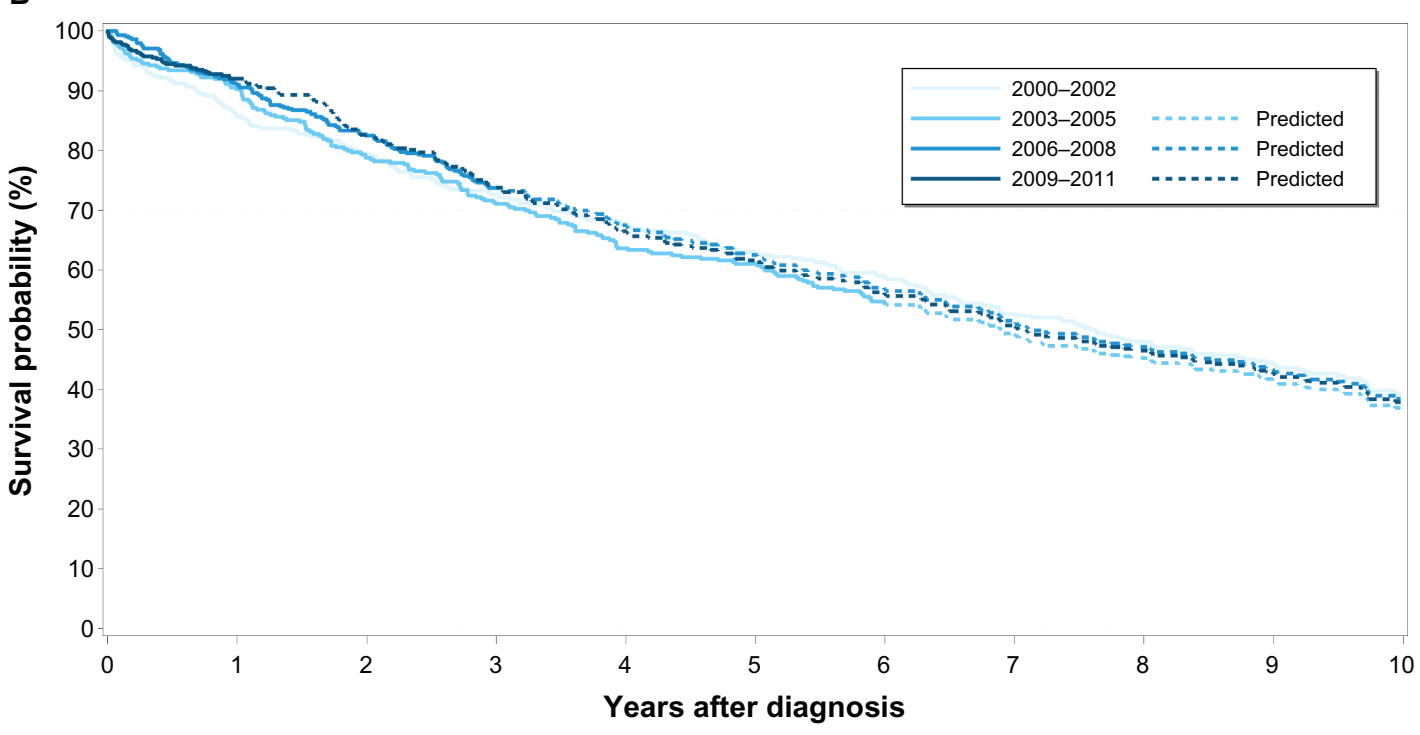

C

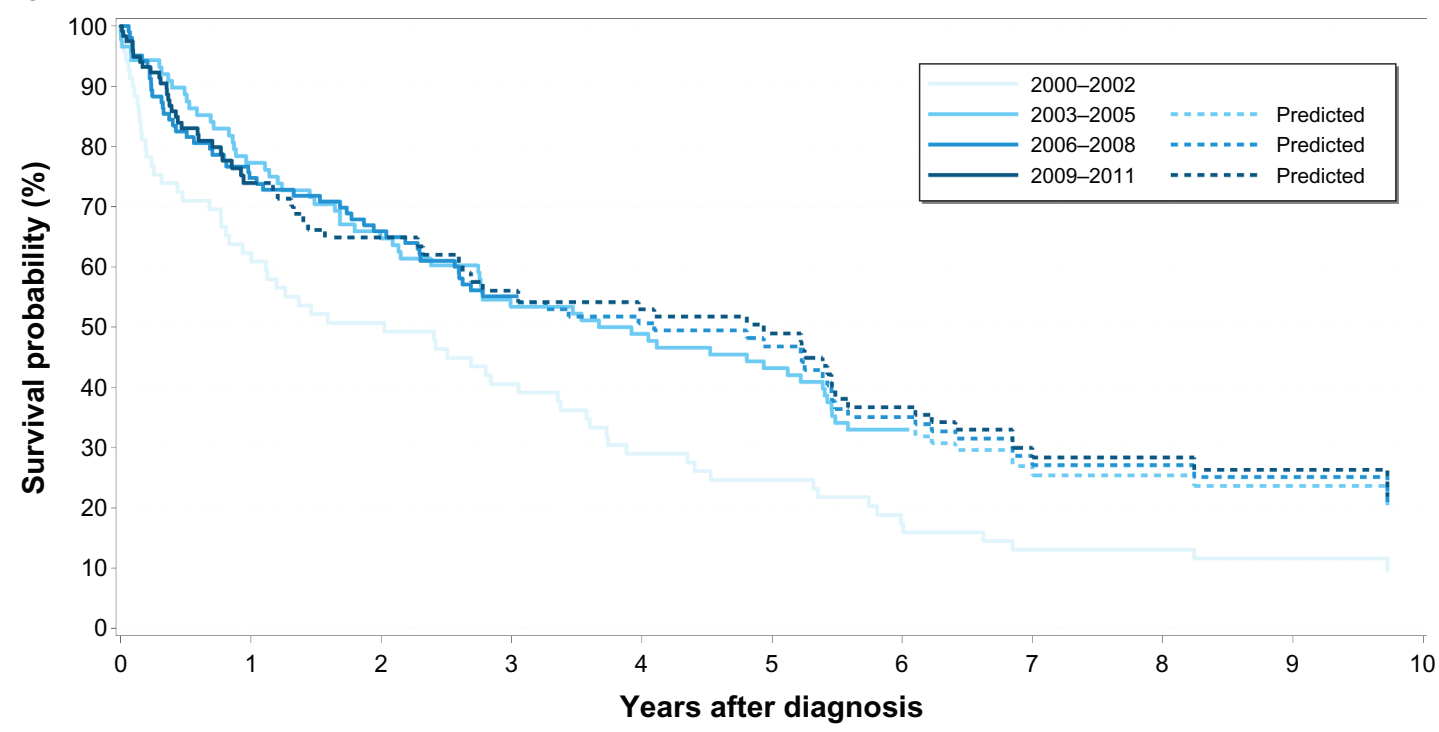

Figure I Kaplan-Meier survival curves for breast cancer patients in four calendar time periods stratified by Charlson Comorbidity Index score. Notes: (A) Charlson score $=0$; (B) Charlson score $=1-2 ;$ (C) Charlson score $\geq 3$. 
not indicate any improvement in 5-year survival for patients with a CCI score of $\geq 3,{ }^{14}$ we observed a marked improvement in predicted 5-year survival for patients with a CCI score of $\geq 3$ during the calendar period from 2000-2011. However, this may be due to chance, because the survival of the 69 patients diagnosed in the reference period (2000-2002) was relatively poor compared with the following calendar time periods, so it is difficult to make any conclusions on these findings. Introduction of the national Danish mammography screening program for women 50-69 years of age in 2007 is expected to result in an increased number of patients in this age group, which is consistent with our findings, as well as more patients diagnosed with early-stage breast cancer and thereby in need of less extensive treatment, since less extensive treatment is well tolerated regardless of comorbidity level. This may decrease the survival gap related to comorbidity.

Although comorbidity is associated with a poorer prognosis in breast cancer, we observed a modest improvement in survival, which may suggest improved management of breast cancer patients with comorbidity over time.

\section{Acknowledgments}

Cancer analyses in the Central Denmark Region were conducted as part of the Aarhus University Disease Epidemiology and Outcomes (AUDEO) Project at the Department of Clinical Epidemiology, Aarhus University Hospital.

\section{Disclosure}

The authors report no conflicts of interest in this work.

\section{References}

1. Organisation for Economic Co-operation and Development. Health at a Glance: Europe 2012. Available from: http://dx.doi. org/10.1787/9789264183896-en. Accessed July 12, 2013.

2. Engholm G, Ferlay J, Christensen N, et al. NORDCAN - a Nordic tool for cancer information, planning, quality control and research. Acta Oncol. 2010;49(5):725-736.

3. Extermann M. Measurement and impact of comorbidity in older cancer patients. Crit Rev Oncol Hematol. 2000;35(3):181-200.

4. Ogle KS, Swanson GM, Woods N, Azzouz F. Cancer and comorbidity: redefining chronic diseases. Cancer. 2000;88(3):653-663.

5. Cronin-Fenton DP, Nørgaard M, Jacobsen J, et al. Comorbidity and survival of Danish breast cancer patients from 1995 to 2005. Br J Cancer. 2007;96(9):1462-1468.

6. Patnaik JL, Byers T, Diguiseppi C, Denberg TD, Dabelea D. The influence of comorbidities on overall survival among older women diagnosed with breast cancer. J Natl Cancer Inst. 2011;103(14):1101-1111.

7. Ring A, Sestak I, Baum M, et al. Influence of comorbidities and age on risk of death without recurrence: a retrospective analysis of the Arimidex, Tamoxifen Alone or in Combination trial. J Clin Oncol. 2011;29(32): 4266-4272.
8. Riihimaki M, Thomsen H, Brandt A, Sundquist J, Hemminki K. Death causes in breast cancer patients. Ann Oncol. 2012;23(3):604-610.

9. Bush D, Smith B, Younger J, Michaelson JS. The non-breast-cancer death rate among breast cancer patients. Breast Cancer Res Treat. 2011;127(1):243-249.

10. Schonberg MA, Marcantonio ER, LiD, Silliman RA, Ngo L, McCarthy EP. Breast cancer among the oldest old: tumor characteristics, treatment choices, and survival. J Clin Oncol. 2010;28(12):2038-2045.

11. Janssen-Heijnen ML, Houterman S, Lemmens VE, Louwman MW, Maas HA, Coebergh JW. Prognostic impact of increasing age and comorbidity in cancer patients: a population-based approach. Crit Rev Oncol Hematol. 2005;55(3):231-240.

12. Jørgensen TL, Hallas J, Friis S, Herrstedt J. Comorbidity in elderly cancer patients in relation to overall and cancer-specific mortality. $\mathrm{Br}$ J Cancer. 2012;106(7):1353-1360.

13. Lietzen LW, Sørensen GV, Ording AG, et al. Survival of women with breast cancer in central and northern Denmark, 1998-2009. Clin Epidemiol. 2011;3 Suppl 1:35-40.

14. Land LH, Dalton SO, Jensen MB, Ewertz M. Impact of comorbidity on mortality: a cohort study of 62,591 Danish women diagnosed with early breast cancer, 1990-2008. Breast Cancer Res Treat. 2012;131(3): $1013-1020$.

15. Charlson ME, Pompei P, Ales KL, MacKenzie CR. A new method of classifying prognostic comorbidity in longitudinal studies: development and validation. J Chronic Dis. 1987;40(5):373-383.

16. Pedersen CB. The Danish Civil Registration System. Scand J Public Health. 2011;39(Supp1 7):22-25.

17. Lynge E, Sandegaard JL, Rebolj M. The Danish National Patient Register. Scand J Public Health. 2011;39(Suppl 7):30-33.

18. Klabunde CN, Legler JM, Warren JL, Baldwin LM, Schrag D. A refined comorbidity measurement algorithm for claims-based studies of breast, prostate, colorectal, and lung cancer patients. Ann Epidemiol. 2007; 17(8):584-590.

19. Brenner H, Rachet B. Hybrid analysis for up-to-date long-term survival rates in cancer registries with delayed recording of incident cases. Eur J Cancer. 2004;40(16):2494-2501.

20. [Short and long term survival after hospitalization for selected cancer diseases in North Jutland County, Viborg County and Aarhus County.] Kortog Langtidsoverlevelse Efter Indlaggelse for Udvalgte Kraftsygdomme $i$ Nordjyllands, Viborg og Arhus Amter 1985-2003. Department of Clinical Epidemiology, Aarhus University Hospital; 2004. Available from: http:// kea.au.dk/files/28.pdf. Accessed January 21, 2013. Danish.

21. Thygesen SK, Christiansen CF, Christensen S, Lash TL, Sørensen HT. The predictive value of ICD-10 diagnostic coding used to assess Charlson comorbidity index conditions in the population-based Danish National Registry of Patients. BMC Med Res Methodol. 2011;11:83.

22. Gonzalez EC, Ferrante JM, Van Durme DJ, Pal N, Roetzheim RG. Comorbid illness and the early detection of cancer. South Med J. 2001;94(9):913-920.

23. Yasmeen S, Xing G, Morris C, Chlebowski RT, Romano PS. Comorbidities and mammography use interact to explain racial/ethnic disparities in breast cancer stage at diagnosis. Cancer. 2011;117(14):3252-3261.

24. Yancik R, Wesley MN, Ries LA, Havlik RJ, Edwards BK, Yates JW. Effect of age and comorbidity in postmenopausal breast cancer patients aged 55 years and older. JAMA. 2001;285(7):885-892.

25. Berglund A, Wigertz A, Adolfsson J, et al. Impact of comorbidity on management and mortality in women diagnosed with breast cancer. Breast Cancer Res Treat. 2012;135(1):281-289.

26. Hancke K, Denkinger MD, König J, et al. Standard treatment of female patients with breast cancer decreases substantially for women aged 70 years and older: a German clinical cohort study. Ann Oncol. 2010;21(4):748-753. 


\section{Supplementary tables}

Table SI Specification of Charlson diseases, International Classification of Diseases (ICD)-8 and ICD-I0 codes, and the Charlson weight

\begin{tabular}{|c|c|c|c|}
\hline $\begin{array}{l}\text { Charlson comorbidity } \\
\text { index variable }\end{array}$ & ICD-8 & ICD- 10 & $\begin{array}{l}\text { Charlson } \\
\text { weight }\end{array}$ \\
\hline Myocardial infarction & 410 & $121,122,123$ & I \\
\hline Congestive heart failure & $\begin{array}{l}427.09,427.10,427.11,427.19 \\
428.99,782.49\end{array}$ & $150,1 \mid 1.0,113.0,113.2$ & 1 \\
\hline Peripheral vascular disease & $440,44 I, 442,443,444,445$ & 170, I7I, I72, I73, I74, I77 & I \\
\hline Cerebrovascular disease & $430-438$ & 160-169, G45, G46 & I \\
\hline Dementia & $290.09-290.19,293.09$ & F00-F03, F05.I, G30 & 1 \\
\hline Chronic pulmonary disease & $490-493,515-518$ & $\begin{array}{l}\text { J40-J47, J60-J67, J68.4, J70.I, J70.3, } \\
\text { J84.।, J92.0, J96.I, J98.2, J98.3 }\end{array}$ & 1 \\
\hline Connective tissue disease & $712,716,734,446,135.99$ & $\begin{array}{l}\text { M05, M06, M08, M09, M30, M31, } \\
\text { M32, M33, M34, M35, M36, D86 }\end{array}$ & I \\
\hline Ulcer disease & $530.9 \mathrm{I}, 530.98,53 \mathrm{I}-534$ & $\mathrm{~K} 22 . \mathrm{I}, \mathrm{K} 25-\mathrm{K} 28$ & I \\
\hline Mild liver disease & 57I, 573.0I, 573.04 & $\begin{array}{l}\mathrm{B} 18, \mathrm{~K} 70.0-\mathrm{K} 70.3, \mathrm{~K} 70.9, \mathrm{~K} 7 \mathrm{I}, \mathrm{K} 73 \text {, } \\
\mathrm{K} 74, \mathrm{~K} 76.0\end{array}$ & I \\
\hline Diabetes type I & $249.00,249.06,249.07,249.09$ & EI0.0, EIO.I, EI0.9 & 1 \\
\hline Diabetes type 2 & $250.00,250.06,250.07,250.09$ & EII.0, EII.I, EII.9 & \\
\hline Hemiplegia & 344 & G8I, G82 & 2 \\
\hline Moderate-to-severe renal disease & $\begin{array}{l}403,404,580-583,584,590.09, \\
593.19,753.10-753.19,792\end{array}$ & $\begin{array}{l}\text { II 2, II3, N00-N05, N07, NII, NI4, } \\
\text { NI7-NI9, Q6I }\end{array}$ & 2 \\
\hline Diabetes with end organ damage & & & 2 \\
\hline Type I & $249.01-249.05,249.08$ & EI0.2-EI0.8 & \\
\hline Type 2 & $250.01-250.05,250.08$ & EII.2-EII.8 & \\
\hline Any tumor & $140-194$ & $\mathrm{C} 00-\mathrm{C} 75$ & 2 \\
\hline Leukemia & 204-207 & $\mathrm{C} 91-\mathrm{C} 95$ & 2 \\
\hline Lymphoma & $200-203,275.59$ & C8I-C85, C88, C90, C96 & 2 \\
\hline Moderate-to-severe liver disease & $\begin{array}{l}070.00,070.02,070.04,070.06 \\
070.08,573.00,456.00-456.09\end{array}$ & $\begin{array}{l}\text { BI5.0, BI6.0, BI6.2, BI9.0, K70.4, } \\
\text { K72, K76.6, } 185\end{array}$ & 3 \\
\hline Metastatic solid tumor & $195-198,199$ & $\mathrm{C} 76-\mathrm{C} 80$ & 6 \\
\hline AIDS & 079.83 & B2I-B24 & 6 \\
\hline
\end{tabular}

Table S2 Distribution of breast cancer patients diagnosed between 2000 and $201 \mathrm{I}$ by individual Charlson disease in four calendar time periods

\begin{tabular}{|c|c|c|c|c|c|c|c|c|c|c|}
\hline & \multicolumn{8}{|c|}{ Calendar time period } & \multirow{2}{*}{\multicolumn{2}{|c|}{ All }} \\
\hline & \multicolumn{2}{|c|}{ 2000-2002 } & \multicolumn{2}{|c|}{$2003-2005$} & \multicolumn{2}{|c|}{ 2006-2008 } & \multicolumn{2}{|c|}{$2009-2011$} & & \\
\hline & $\mathbf{N}$ & $\%$ & $\mathbf{N}$ & $\%$ & $\mathbf{N}$ & $\%$ & $\mathbf{N}$ & $\%$ & $\mathbf{N}$ & $\%$ \\
\hline Myocardial infarction & 28 & $\mathrm{I} .4$ & 36 & 1.8 & 38 & 1.6 & 32 & 1.1 & 134 & 1.4 \\
\hline Congestive heart failure & 43 & 2.2 & 57 & 2.9 & 49 & 2.0 & 47 & 1.6 & 196 & 2.1 \\
\hline Peripheral vascular disease & 52 & 2.6 & 54 & 2.7 & 47 & 2.0 & 69 & 2.3 & 222 & 2.4 \\
\hline Cerebrovascular disease & 79 & 4.0 & 91 & 4.6 & 102 & 4.2 & 116 & 3.9 & 388 & 4.2 \\
\hline Dementia & 6 & 0.3 & 9 & 0.5 & 14 & 0.6 & 16 & 0.5 & 45 & 0.5 \\
\hline Chronic pulmonary disease & 91 & 4.6 & 105 & 5.3 & 134 & 5.6 & 145 & 4.9 & 475 & 5.1 \\
\hline Connective tissue disease & 52 & 2.6 & 37 & 1.9 & 58 & 2.4 & 75 & 2.5 & 222 & 2.4 \\
\hline Ulcer disease & 39 & 2.0 & 36 & 1.8 & 54 & 2.2 & 49 & 1.7 & 178 & 1.9 \\
\hline Mild liver disease & 8 & 0.4 & 4 & 0.2 & 18 & 0.7 & 23 & 0.8 & 53 & 0.6 \\
\hline Diabetes I and II & 37 & 1.9 & 40 & 2.0 & 49 & 2.0 & 73 & 2.5 & 199 & 2.1 \\
\hline Hemiplegia & 7 & 0.4 & 5 & 0.3 & 4 & 0.2 & 4 & 0.1 & 20 & 0.2 \\
\hline Moderate to severe renal disease & 6 & 0.3 & 15 & 0.8 & 27 & 1.1 & 23 & 0.8 & 71 & 0.8 \\
\hline Diabetes with end organ damage & 21 & 1.1 & 41 & 2.1 & 40 & 1.7 & 38 & 1.3 & 140 & 1.5 \\
\hline Any tumor & 80 & 4.0 & 62 & 3.1 & 90 & 3.7 & 130 & 4.4 & 362 & 3.9 \\
\hline Leukemia & 2 & 0.1 & 1 & 0.1 & 0 & 0 & 4 & 0.1 & 7 & 0.1 \\
\hline Lymphoma & 6 & 0.3 & 3 & 0.2 & 12 & 0.5 & 9 & 0.3 & 30 & 0.3 \\
\hline Moderate-to-severe liver disease & 3 & 0.2 & 3 & 0.2 & 5 & 0.2 & 3 & 0.1 & 14 & 0.2 \\
\hline Metastatic solid tumor & 7 & 0.4 & 16 & 0.8 & 22 & 0.9 & 22 & 0.7 & 67 & 0.7 \\
\hline AIDS & 0 & 0 & 0 & 0 & 0 & 0 & 0 & 0 & 0 & \\
\hline Total & 1,980 & 100 & 1,994 & 100 & 2,410 & 100 & 2,945 & 100 & 9,329 & 100 \\
\hline
\end{tabular}




\section{Publish your work in this journal}

Clinical Epidemiology is an international, peer-reviewed, open access journal focusing on disease and drug epidemiology, identification of risk factors and screening procedures to develop optimal preventative initiatives and programs. Specific topics include: diagnosis, prognosis, treatment, screening, prevention, risk factor modification, systematic

Submit your manuscript here: http://www.dovepress.com/clinical-epidemiology-journal reviews, risk \& safety of medical interventions, epidemiology \& biostatical methods, evaluation of guidelines, translational medicine, health policies \& economic evaluations. The manuscript management system is completely online and includes a very quick and fair peer-review system, which is all easy to use. 